\title{
The Swedish Railway Deregulation Path
}

\author{
GUNNAR ALEXANDERSSON * \\ Department of Marketing, Distribution \& Industry Dynamics, Stockholm School of Economics \\ STAFFAN HULTÉN \\ Department of Marketing, Distribution \& Industry Dynamics, Stockholm School of Economics
}

\begin{abstract}
This paper deals with railway deregulation and related reforms by means of a case study of Sweden, studying the 1988 split of railway infrastructure from operations and the subsequent steps of vertical and horizontal disintegration to a market characterized by decentralization and intra-modal competition. We also analyze the current market situation, in terms of the actors and their roles, and industrial organization measures. This assessment is used to discuss the sustainability of the current regulatory structure, concluding that although it seems more sustainable than in the past, regulators will sooner or later have to deal with some of its inconsistencies.
\end{abstract}

\section{Introduction}

Since the late 1980s, several countries in Europe have gradually started to reform their national railway monopolies, using vertical separation of infrastructure from operations, introducing intra-modal competition by various procedures and contracts, and sometimes partial privatization of the railway industry. While some countries have clearly been pioneers in this respect, we have also seen the rise of common EU policies, eventually affecting all member states.

In this paper, we discuss the Swedish process of reforming the railways in the past decades. The first part of the paper deals with the economic and legal reasons for a deregulation of the railway sector and discusses the potential contribution of case study research of regulatory reforms. In a second part of the paper, we turn to Sweden, looking at the development since 1988, including the most important effects and the current market situation. This assessment is then used as a foundation for a concluding discussion of the direction of the evolution of the Swedish reforms and the sustainability of the present regulatory structure, set in the context of the agenda for further reforms on the EU level.

\footnotetext{
* Contact Author. Department of Marketing, Distribution \& Industry Dynamics, Stockholm School of Economics, P.O. Box 6501, SE-113 83 Stockholm, Sweden. E-mail: Gunnar.Alexandersson@hhs.se The financial support from Banverket is gratefully acknowledged. We also thank Lars Persson at the Research Institute of Industrial Economics (IUI), Stockholm, and one anonymous referee for valuable comments on an early version of this paper.
} 


\section{Perspectives on railway deregulation}

Deregulations are commonly linked to market transitions that involve privatization, the transfer of public ownership and management to the private sector. According to Vickers and Yarrow (1991) privatization of former public enterprises and services can take three forms: 1) Privatization of competitive firms - the transfer to the private sector of stateowned enterprises operating in competitive markets. 2) Privatization of monopolies transfer to the private sector of state-owned enterprises with substantial market power. These firms can either be natural monopolies (like electricity transmission) or "artificial" monopolies, where competition from foreign or domestic firms could exist. 3) Contracting out of publicly financed services, previously performed by public sector organizations.

The economic motives for privatizing a public monopoly compared to replacing a public monopoly with competition are quite different. There exists a widespread agreement that the replacement of a public or publicly guaranteed private monopoly with competition between competing firms results in improved efficiency. The efficiency gains are less clear for the transfer of a public monopoly to private ownership. In this case, it seems that the regulatory policy is crucial for preventing negative effects of monopoly power. The motives for selling a public monopoly are rather found in the need to find revenues for the public sector or avoiding public spending in the future.

The research on the deregulation of the American railroad industry in the period 1976 to 1980 , most importantly the Staggers Rail Act in 1980, has nearly exclusively focused on the freight sector and the deregulation's effect on price and quality (Uri and Rifkin, 1985; McFarland, 1987; and Wilson, 1994). The American railway market is predominantly a freight market and the principal goal of the deregulation was to allow the private railway operators more freedom of action. The European (EU) deregulation context 15-25 years later is radically different from the US deregulation. EU railway networks serve both passenger and freight markets, and both these markets have been deregulated. Deregulation in Europe means both changes in the regulatory structure and a gradual or complete privatization of the former vertically integrated state monopolies. The major arguments for reforms, as stated by the European Commission, have been to create a common European market for railway transportation services, railway material and equipment, and to overcome different technical standards and other obstacles in order to make the railways more competitive compared to other modes of transportation. The freight sector has been relatively more deregulated than the passenger services and it should be possible to rerun the research from the US deregulation on the EU experience. Levin (1981) cautioned against being too optimistic about the possibilities of achieving optimality in the deregulated market. He suggested that in the case of railroads, indivisibilities, pervasive economies of joint production, and high costs of entry leading inevitably to small-numbers competition in the deregulated market, pose problems of the regulatory framework after deregulation. His solution was to safeguard "workable inter-railroad competition" and to use price ceilings to reduce deadweight loss in a future monopolistic market.

Four broad types of deregulation approaches are apparent in the member states of the EU. The British rationalist approach, the Swedish incremental approach, the German and Dutch "wait and see" incremental approach and the French late compliance approach. In comparison with EU legislation, the British deregulation has nearly always been substantially ahead, the Swedish deregulation in most cases ahead, the German and Dutch in tune with EU legislation and the late compliers significantly behind. (See, for example, 
Héritier et al (2001), for a thorough discussion of the EU impact on railway reforms and the differences in national policymaking between UK, France, Germany and the Netherlands.)

The British deregulation was initiated and carried out during a relatively short time period from 1994 to 1997, and consisted of a break-up vertically and horizontally and total privatization of the former integrated monopoly. The deregulation created three types of private companies that came to dominate the post-deregulation market. Railtrack got the responsibility for the infrastructure, rolling-stock companies (Roscos) became owners of the rolling stock (then leased to the operators), and 25 train operating companies took control of the railway services. The operators were selected using a franchising procedure, characterized by competitive bidding, where the lowest demanded subsidy (or even highest payments to the Government) was among the most important selection criteria. New Governmental bodies, such as the franchising authority OPRAF and the Rail Regulator were supposed to monitor the market actors. Since then, the institutional framework has subsequently been altered on several occasions. Railtrack has in effect been renationalized, new public agencies have replaced the former and the subsidies have not decreased according to the initial plan. The Swedish case history (presented in more detail below) shows that similar changes have occurred, albeit at a slower speed. The retrograde steps have also been fewer and less dramatic.

The British deregulation of the railway sector used the two last privatization measures mentioned above - privatization of monopoly rights and contracting out of public services. Most of the deregulation examples from other EU countries are primarily of the third type. However, some countries have transferred former monopoly firms to private or foreign firms. For example, Denmark and the Netherlands have sold their national railway freight companies to Railion - a firm originating in the former freight division of Deutsche Bahn.

The deregulation of the railway sector in the EU member states seems to have been driven by different types of economic, institutional and legal concerns. In Britain, we find that the pursuit of a market liberal agenda has dominated. In Sweden, key concerns have been the need to find new ways to finance investments in the railway sector, and to increase efficiency through competition. In countries like France and Portugal the initial most important factor seems to have been the necessity to act in accordance with EU legislation. However, both countries have later begun to exploit the potential of the reforms, with attempts to attract new actors and introduce actual competition (see, for example, Railway Gazette International (2006)).

The research on the railway deregulation in Europe has to a large extent looked at the effects of competition in terms of lower subsidies, productivity changes and entry barriers. Some observers have questioned if the European solution with vertical separation and competitive tendering is a better option than (for example) a privatization of the former state monopolies. They argue that scale economies in operation, indivisibilities and economies of vertical integration are too significant to be overlooked (see for example Ehrmann, 2003). The British deregulation has been much discussed and different aspects of the rapid deregulation have been criticized. Nash and Smith (2006) have pointed at the disappointing long-term development of train operator costs that followed after the early promising projections. Yvrande-Billon and Menard (2005) suggest that transaction costs may have been higher than expected because of a lack of coordination between contract lengths and the assets (rolling stock) used for railway services. This result in a 
misalignment: an arrangement in which the characteristics of the mode of organization do not fit the attributes of the transaction it has to organize.

From the discussion above, we can notice that the European deregulation of the railway system has been different than the American deregulation. Price and quality changes of the freight services are far from the only concern in European research. The European countries advance at different speed using different ways of deregulating the railway system resulting in relatively smaller samples than in the US railway freight market. We therefore argue that case study research has a more important role to play in the European case than in the research of the American deregulation.

This article has three objectives. The first objective is to describe the deregulation process in Sweden and the current railway system with its regulatory structures and actors in the form of a case study. The second objective is to analyze the present railway markets in some simple industrial organization measures: concentration ratios, barriers to entry, transaction costs, vertical integration and economic efficiency trends. The third objective is to discuss the sustainability of the Swedish regulatory reform path and critical issues for the future.

\section{A principal discussion on case studies}

The research method in this article is a reconstructed case study, based on interviews, reports, annual reports, political documents, press releases and scientific articles. The regulatory reforms in the European transport sector have to-date been discussed and analyzed in a large number of case studies. Some case studies have a theoretical orientation, using theoretical constructs to question how efficient the reforms were, such as the transaction cost analysis of Yvrande-Billon and Menard (2005). Other case studies use industrial organization concepts - measures of industry concentration, horizontal and vertical disintegration and so on - to analyze the regulatory reforms (Alexandersson et al, 2000; Nash, 1993; Nilsson, 2002; and Preston, 2001). A third type of case study is nearly purely descriptive; see, for example, Kirchner (2005) and most of the contributions in Van de Velde (1999), presenting how far deregulation has proceeded and the nature of the reforms. These case studies answer to a demand for general information on the deregulation movement by public agencies, private firms and researchers. We position this article as being somewhere in between the first and the second type of the case studies.

There is a long tradition of using case studies as analytical tools for research within the field of Industrial Organization, dating back to pioneering work by, for example, Marshall, Chamberlin and J. M. Clarke. Detailed empirical studies of specific industries have given input to a better general understanding of industries, markets and firms, also contributing to theoretical development. Statistical analysis and econometrics are traditional tools but qualitative information gathered by direct observation and interviews has also been shown to provide supplemental economic evidence to various propositions (Borenstein et al, 1998). Proponents of a grounded theory approach to developing economic theory and generalizations specifically point at the systematic and comparative use of both qualitative and quantitative case studies (Finch, 2002).

Case studies are also believed to be a highly useful tool for researching industries in transition (Westgren \& Zering, 1998), such as when regulatory reforms and increased competition set of a transformation of industry market structure. By using case studies 
where the unit of observation is a specific country and its experiences from industry reform and transition, it may be possible for economists to, for example, provide policymakers in other countries with generalizable information and insights. This could be one way to react to a growing concern that economic theory has become increasingly abstract and detached from real-world problems, while policymakers may rely too much on rules of thumb that have not been tested scientifically (several contributors deal with this tension in Van Bergeijk et al, 1997).

\section{Swedish railways - overview of changes in the regulatory framework}

The Swedish deregulation process started in earnest in 1988. By that time the Swedish railway sector was more or less synonymous with Swedish State Railways (SJ), a stateowned business administration with a monopoly position on both freight and passenger rail services, protected from competition by means of laws and regulations (Table 1). Apart from being responsible for and controlling all aspects of the railway services, SJ was also involved as owner or co-owner in supporting businesses such as ferry traffic, long-distance bus services and forwarding agents. For the freight services, SJ was a contracted operator. For the passenger services, an overwhelming majority of the lines were run by SJ under its own account, that is, without the use of contracts with the state or any other authorities. For those passenger services that were unprofitable but considered important for socioeconomic and political reasons, the Parliament every year granted SJ the amount of money it demanded to cover the deficits. On a limited number of passenger lines, SJ worked as the contracted operator to regional (county level) public transport authorities.

\begin{tabular}{|c|c|c|}
\hline Part of market & 1988 & 2007 \\
\hline \multicolumn{3}{|l|}{ Passenger services } \\
\hline Regional (non-profitable) & $\begin{array}{l}\text { SJ holds monopoly and } \\
\text { receives subsidies }\end{array}$ & $\begin{array}{l}\text { Procurement by } \\
\text { competitive tendering } \\
\text { (competition for the } \\
\text { tracks) }\end{array}$ \\
\hline Inter-regional (non-profitable) & $\begin{array}{l}\text { SJ holds monopoly and } \\
\text { received subsidies }\end{array}$ & $\begin{array}{l}\text { Procurement by } \\
\text { competitive tendering } \\
\text { (competition for the } \\
\text { tracks) }\end{array}$ \\
\hline Inter-regional (profitable) & SJ holds monopoly & SJ holds monopoly \\
\hline Freight services & SJ holds monopoly & $\begin{array}{l}\text { Open access on all lines } \\
\text { (competition on the } \\
\text { tracks) }\end{array}$ \\
\hline
\end{tabular}

Table 1: Regulatory structure of the Swedish railway sector in 1988 and 2007

In the year 2007, the rail infrastructure is owned and maintained by a national authority, Banverket, also handling the train traffic control function. Public procurement by competitive tendering dominates the passenger rail market, being applied on almost all the unprofitable lines, which make up the majority of the all railway lines. SJ has been disintegrated into several specialized companies, some of which have been privatized, 
while others are still state-owned. One of these, SJ AB (SJ Ltd), originating from the former passenger division, continues to be Sweden's biggest train operator. SJ AB still runs services under its own account but is also to a large extent operating under contract to regional and national transport authorities. The market for freight services is deregulated, implying open access to virtually all parts of the railway network. Green Cargo AB, the successor to SJ's freight division, still dominates this part of the market. The only part of the railway transportation market where SJ AB still holds a legal monopoly concerns the inter-regional passenger services that the company considers possible to run with a profit (that is, in principle the important lines between Stockholm and some other major cities). The company still controls most of the rolling stock but regional transport authorities and private freight operators own a considerable amount of vehicles.

In order to understand how this shift came about, we will briefly recapitulate the history of Swedish railway reforms in the next section.

\section{$5 \quad$ The process of Swedish railway reforms ${ }^{1}$}

Regulatory changes in the Swedish railway sector have often emanated from a wish to come to terms with the recurrent financial difficulties of SJ. There is an important prehistory of reforms beginning already in the 1960s, but the Transport Policy Act of 1988, with its ground-breaking split of railway infrastructure from operations, is commonly considered the starting point for the transformation of the Swedish railway system - from a vertically and horizontally integrated monopoly to a market characterized by decentralization and intra-modal competition.

The Transport Policy Act of 1988 had the objective to make the conditions for the railways more similar to those for the roads. The state took the full responsibility for railway infrastructure investments and maintenance by means of a new authority Banverket, while SJ would transform into a train operating company, paying charges for using the tracks (based upon marginal costs for maintenance). Infrastructure investments were to be evaluated by means of socio-economic calculations. Among its several other components, the Act also marked a general policy step in the direction of extending the responsibility of the County Public Transport Authorities (CPTAs) - established in 1979 to coordinate regional public bus services - into the unprofitable regional railway services, inspired by some early cases where this had been tried. In return, the CPTAs were compensated by state subsidies equaling SJ's operating deficits on these lines and the rolling stock was also transferred to the CPTAs.

A deregulation of the railways in terms of increased intra-modal competition was not explicitly mentioned in the Act. Nevertheless, the vertical separation of infrastructure from operations, combined with the decentralized responsibility for regional railway services to regional authorities (along with the necessary money and rolling stock), made public procurement by competitive tendering of these lines possible. Some CPTAs had already tried tendering procedures for their bus services, as a result of previous reforms in that sector. This made it natural to use competitive tendering also of regional railway lines. The outcome was the first new entrant for more than 40 years, BK Tåg, in 1990.

\footnotetext{
${ }^{1}$ This section draws from Alexandersson et al (2000), Alexandersson (2002), Nilsson (1995) and Van de Velde (1999, pp.79-141).
} 
In the beginning of 1991, the Ministry of Transport expressed the view that more operators would stimulate the railway industry to make use of its resources in a more efficient way. At the time, there was a perceived fear among many politicians that SJ's power on the transportation market could become too strong, especially since SJ's management had been unwilling to concentrate on the railway services, keeping SJ a much diversified transportation conglomerate. After a shift in power in Parliament in September the same year, a new centre-right-wing government declared its objective to open the railways to more competition. The first step was to subject more railway traffic to tendering. When SJ got rid of the responsibility for track infrastructure, it had been directed only to perform profitable train services under its own account. While large parts of the unprofitable services were run on the regional lines, therefore under the responsibility of the CPTAs, many services of the inter-regional main line network were also unprofitable. Since 1988, the state had been procuring these services by means of annual negotiations with SJ, instead of simply transferring subsidies to SJ every year to cover the deficits. In 1992, following the experiences of tendering of regional services, a regulatory change made it possible also for the state's negotiator to use competitive tendering when procuring services on the inter-regional lines.

In 1993-94 several reports looking into the feasibility of deregulating the whole network followed, coupled with a fierce political debate. In May 1994, a bill on a farreaching deregulation was passed in Parliament, despite heavy opposition from the Social Democrats, the left-wing party and the railway unions. Consequently, when the Social Democrats regained power in Parliament through the election in September the same year, the deregulation of the railways was quickly postponed. Instead, a less radical reform was suggested, coming into effect in July 1996. The functions of allocation of track capacity and train traffic control were transferred from SJ to Banverket, while other common facilities were to be available for other train operators under commercial but nondiscriminating terms. The CPTAs' rights were extended, making it easier for them to replace reductions in SJ's supply of inter-regional trains with regional CPTA-managed services. Consequently, the practice of competitive tendering became available for more parts of the railway network. For the freight services, open access on the whole network was introduced, based upon the belief that these services would stand better chances against other modes of transportation if they were forced to adapt to what the market wanted. Actual access to capacity was only limited by a "Grandfather's right” clause, giving an operator the right of precedence to a timetable position it had used before. In practice, this rule was rarely (if ever) enforced and was eventually abandoned in 2004.

A new Transport Policy Bill was passed in 1998. In an effort to achieve more equal terms for competing modes of transportation, in particular concerning freight, the track access fees were lowered. In order to make entry easier for freight operators competing with SJ, some fringe railway lines that had remained in SJ's hands were transferred to Banverket. Moreover, a new national authority, Rikstrafiken, was established. The authority took over the tasks of the former state's negotiator, becoming responsible for competitive tendering of unprofitable inter-regional services (including all modes of public transportation), aiming also at better co-ordination with the CPTA-tendered services. Following the inflow of new operators in 2000, a new Bill had the objective to facilitate for SJ to compete under the new circumstances and to ensure equal access to functions and services for all operators. SJ's organizational structure as a business administration was therefore replaced in 2001 by several state-owned companies concentrating on specified 
parts of the railway businesses. The passenger division formed one company (SJ Ltd), the freight division another (Green Cargo), and so on for real estate (Jernhusen), maintenance (EuroMaint) and other businesses. Two divisions, TraffiCare (cleaning services) and Unigrid (computer information systems), were fully privatized a few months later. EuroMaint and SweMaint were initially also set to be privatized rather quickly but this process was not completed until 2007. All this is summarized in Figure 1, also including some of the previous divestments and separations from the business administration SJ. In the figure, firms and organizations presented in red boxes are still state-owned, while the companies in green boxes are now in the private sector.

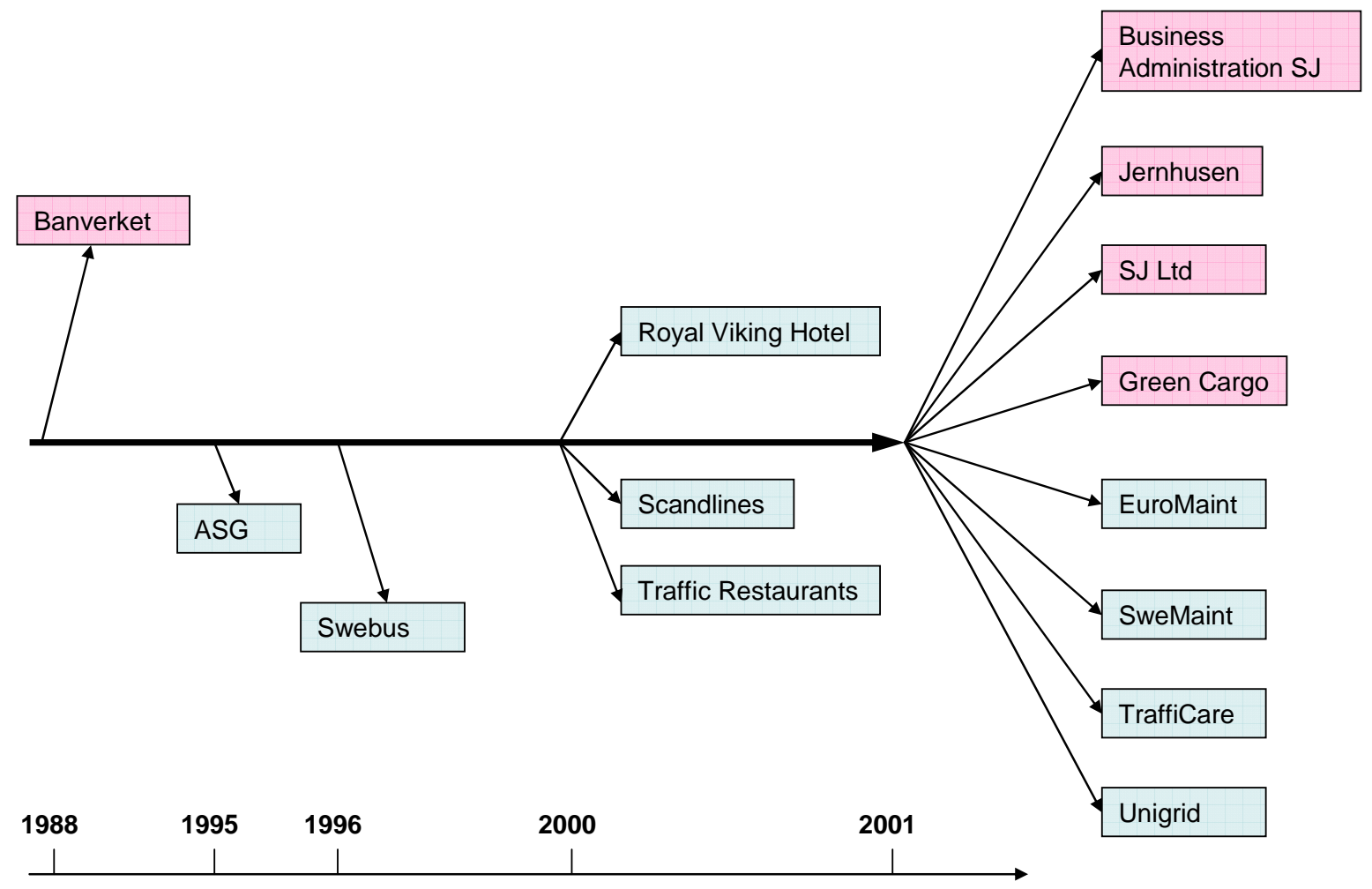

Figure 1: The separation of the business administration SJ 1988-2001

Since the Bill of 2000, the process of regulatory change in the Swedish railway sector has to some extent slowed down. On several occasions, it has been suggested that the remaining monopoly of SJ Ltd concerning the profitable inter-regional lines should be abolished, possibly opening up for open access or at least competitive tendering on these lines. The Social Democrat government (in power until late 2006) was unwilling to take this step, motivated by a perceived need for more time to evaluate the effects of the already implemented reforms. In 2003, the state had to interfere by means of transferring a large amount of money (1.8 billion SEK) to SJ Ltd from other state-owned companies in order to avoid bankruptcy (Proposition (2002/03:86). It had then become clear that the breaking-up of SJ into several separate companies had been an under-financed reform but also that several of SJ's contracts for regional and inter-regional passenger services were highly unprofitable due to the fact that SJ had won the tendered contracts with too low bids.

The most recent reforms have focused on modernizing laws and regulations to achieve a regulatory framework in line with European Union directives. Following the European 
Commission's first railway package, a new railway law and railway regulation came into effect in July 2004, and a new Swedish Rail Agency was established (SFS 2004:519, SFS 2004:526). During 2005-2006, a new transport policy bill was in preparation. One important issue was how Sweden should prepare for a future decision on the European Commission's third railway package and the opening up of international passenger railway services between member states from 2010. In the end, a "wait-and-see"-approach was chosen, keeping most of the regulatory framework unchanged. The new center-right-wing government (established after the Parliament election in 2006) looks set to once again look into the prospects for a continued deregulation.

\section{The Swedish railway system - actors and roles}

The current framework of the Swedish railway market implies that the national authority Banverket owns and maintains the state's railway infrastructure. Since this amounts to about $80 \%$ of all railway lines, Banverket is the primary rail infrastructure holder (Banverket, 2004). Regional authorities own a couple of lines, mainly in the Stockholm region. In addition to this, several minor fringe lines are owned by factories and municipalities. Banverket gets its financial resources mostly from national grants, decided by Parliament for multiple-year-periods but also handles the track access charges paid by operators for using the tracks. The Government and Parliament have given Banverket the overall responsibility for the development of the railway sector. This sector responsibility comprises railway transportation, as well as tram and underground transportation.

The Train Traffic Control unit within Banverket monitors all train movements on the Swedish railway network. The organization is also responsible for offering the operators good opportunities to run their trains. All the wishes of the operators are coordinated with the objective to find solutions that meet these wishes in the best possible and nondiscriminatory way. Due to track capacity constraints on a large part of the network, Banverket actually allocates planned delays compared to the shortest possible time needed for a particular transportation. The end result of this process is the granting of certain timetable positions ("slots") to each operator, and the production of a corresponding national timetable.

All in all, there are about 500 railway stations where trains stop for passengers. Many of these are very simple stops (controlled by Banverket), with no special buildings or facilities for passengers. Many stations (with or without passenger facilities) are owned and maintained by regional authorities, being used only for local and regional services. About 170 stations are equipped with station buildings on separate estates. 150 of these are owned by Jernhusen, the state-owned company formed out of SJ's old real estate division. In addition to this, there are a large number of terminals and facilities used primarily for freight services, owned by several different actors. Jernhusen is the primary owner of buildings used for maintenance of rolling stock.

One key authority is the newly established Swedish Rail Agency. Formed out of the old Railway Inspectorate, the authority has taken over the tasks concerning safety in the railway, underground and tram systems. It has also been assigned new tasks, such as monitoring that the fees charged for the utilization of the railway infrastructure are determined in a competition-neutral and non-discriminatory manner. The same goes for 
capacity allocation and provision of services. Any operator wishing to operate train services on the Swedish rail network needs to apply for a license from the Rail Agency.

The CPTAs are important players in the market, since they account for much of the procurement of railway services. Generally, they also provide their contracted operators with the necessary rolling stock for these services. Together, some of the CPTAs own a rolling stock company, Transitio, thereby managing a large part of the fleet of regional passenger trains. Firms competing for inter-regional services procured by Rikstrafiken may hire vehicles from the company ASJ (the remains of the business administration SJ), where the leasing contracts of the rolling stock are being handled. SJ Ltd and Green Cargo also hire leased vehicles from ASJ. Consequently, ASJ in several respects functions as a rolling stock company today. Freight operators generally have to get their own rolling stock. Perhaps with the exception of locomotive power, the market for freight vehicles is comparably well developed. The vehicles are more standardized than the rolling stock for passenger trains and independent private owners have been around for quite some time.

Several other companies provide various supporting functions to the operators and other organizations. Some of these came out of the corporatization of SJ, others were divested earlier and yet others are new entrants not originating from SJ. One of the most important companies of the first category is EuroMaint (recently privatized and owned by Ratos), the dominant company for maintenance of railway vehicles. Another actor in maintenance is SweMaint (recently acquired from the state by Kockums Industrier), primarily working with freight vehicles. TraffiCare (owned by ISS) provides terminal services such as cleaning (previously also switching). The former Unigrid (now a part of Cap Gemini Ernst \& Young and Norwegian EDB Teamco) is active in IT services. Like EuroMaint and SweMaint, TraffiCare and Unigrid also stem from the corporatization of SJ.

Currently, about 20 train operating companies use the Swedish state's rail infrastructure, most of them being very small. On the passenger side, the state-owned company SJ Ltd is still the dominant operator. Green Cargo, formed out of the former freight division of SJ, is the largest rail freight operator.

The basic model of competition in the market for passenger services is competition "for the tracks". Once a contract has been won in a tender, the winning firm becomes the sole provider of the specified services during the contract period. There are two main types of contracts in use. For the CPTA-managed services, gross-cost contracts are dominant. The operators bid for the lowest amount of subsidy needed to cover the costs (including a profit) of operating the services. The CPTAs are responsible for planning and marketing of the services and generally take all the revenues from ticket fares during the contract period. The other type of contract is the net-cost contract, generally used by Rikstrafiken for the contracts of inter-regional services. The bidding firm has to project both the costs and the revenues from fares during the contract period, bidding for the minimum amount of subsidy needed to cover the deficit. During the contract period, the operator sells tickets and collects fares, and generally has more freedom to influence the services than under a gross-cost contract. Turning to the freight services, the primarily model in use is one of "open access" or competition "on the tracks".

As should be apparent from above, the State is still a very important actor in the Swedish railway sector and has a number of roles related to railway and transportation policy issues. The state is the owner of SJ Ltd, Green Cargo, Jernhusen, and other companies (and until very recently also controlled EuroMaint and SweMaint), with all the 
responsibilities following from ownership. The state is also responsible for investments and maintenance in railway infrastructure through Banverket and for auditing, safety and regulatory issues through the Rail Agency. The role as owner also has to be combined with the role as the entity responsible for setting up the basic conditions for competition and running firms in society, in this case, the rules of the game in the railway market. In addition to this comes the role of forming the long-term national transport policy. It is a delicate problem for the state to carry out all these roles simultaneously without causing conflicts.

\section{$7 \quad$ Analyzing the reforms - key facts and figures}

\subsection{Competition and entry}

Competition has gradually been introduced and spread in the Swedish railway markets. BK Tåg became the pioneering first new regional passenger train operating company in 1990, but it wasn't until 1995 that another operator entered this part of the market. In the market for inter-regional services, despite being tendered since 1992, the break-through for competing operators did not happen until the year 2000. Turning to the freight services, the first new entrants appeared in the early 1990s. Generally, these were minor freight operators working as sub-contractors to SJ. In 1993, the state-owned ore company LKAB became the first company to get its own operating license on the state's railways, thereby being able to take control of its own transportation needs.

As has been mentioned above, about 20 train operating companies use the Swedish state's rail infrastructure, although most of them are very small. SJ Ltd is still the dominant operator of passenger trains, but firms like Connex, Arriva and Tågkompaniet (owned by NSB) are important competitors. In terms of passenger kilometers, SJ Ltd had a 74\% share of all railway services in 2004, with an 88\% share of the long-distance (more than 100 kilometers) and a 54\% share of the short-distance (less than 100 kilometers) railway services (Banverket, 2005a). These differences reflect the fact that substantial parts of the inter-regional services are affected by SJ Ltd's remaining monopoly rights, while most of the short-distance services have now been tendered at least once. Taken together, the shares of the four largest firms amount to about 95\%. Green Cargo, the largest rail freight operator, has a 74\% market share in rail freight transportation in 2004 (Banverket, 2005a). MTAB is the second largest operator, carrying out the transportation of ore on the Iron Ore Line. Being a subsidiary to the mining company LKAB, it is state-owned too. TGOJ is another important freight operator, but this company is a subsidiary to Green Cargo. Although there are several minor private freight operators, only a few, like BK Tåg's surviving freight division and newcomer Hector Rail actually compete with Green Cargo and TGOJ for the same contracts. It is clear that the buyers of transportation services, that is, the manufacturing firms, have been rather slow to make use of the new competitive market. When they have used it, it has often been aimed at making Green Cargo lower its prices, rather than actually switching to another operator.

In addition to looking at the number of new entrants, it is worthwhile to consider the number of active bidders over time (in the tenders for passenger services). Data from 91 tenders between 1989 and 2005 show that rather few bidders have been active in each tender (Alexandersson and Hultén, 2006). On average, the CPTAs' tenders have attracted 
more bidders (2-3) than the state's tenders (1-2). In recent tenders, the number of bidders has increased. Another observation is that it has generally been difficult for firms to win tenders for a specific line or traffic system twice in a row. Similar results have been presented regarding Great Britain (Nash \& Smith, 2006).

The market for maintenance of passenger vehicles provides us with an interesting example of the development of competition in the supporting industries. The former maintenance unit within SJ, EuroMaint, now has a share of slightly less than 50 percent in this market. Important competitors are operators that combine their traffic operations with maintenance services and train manufacturers like Bombardier and Alstom. Alstom is a new actor in Sweden, being established after having won tenders for delivery of new trains. Several foreign companies are preparing for offering maintenance services on the Swedish market. Among these one should mention Mantena (subsidiary to NSB), the technical division of DSB (primarily interested in strengthening its position in the Swedish part of the Öresund region), and DB, that have expressed strong intentions to establish itself in Sweden.

\subsection{Subsidy effects}

Typically, there have been subsidy reductions in the magnitude of $20 \%$ in the first round of the CPTAs' tenders (Table 2). For the services procured by the state, substantial reductions were accomplished during the first two years of tendering, despite the lack of actual new entry. After that a period of tenders implying stable subsidies followed. When several new firms finally were able to win these tenders in 1999, additional large subsidy reductions (28\%) were achieved.

\subsection{Infrastructure spending and costs}

Since vertical separation in 1988, there has been a substantial surge in public spending on infrastructure investments and renewal. Actually, it is highly probable that the split was absolutely necessary for this development to take place. Prior to separation, SJ suffered from trying to perform services on a network that was under-capitalized. Once a line started to make losses, infrastructure investments typically came to a halt. For the state, it was difficult to grant more money to SJ, partly because it could be seen as unfair from the view of other transportation companies, and partly because it was difficult to monitor how SJ actually spent the money. Setting up the national authority Banverket made it much easier to increase public spending on the railways, since all the money was channeled to a national authority rather than to a specific operator in the transportation industry. The split included an agreement implying that the state committed itself to spending at least one billion SEK per year on infrastructure investments while SJ would concentrate on becoming an efficient railway operator. During the recession of the early 1990s, public spending on infrastructure investments increased to about three billion SEK per year. Environmental concerns and political objectives of achieving sustainable development have made it possible for this trend to continue, and for the years to come investments of approximately 10 billion SEK per year are forecasted. 


\begin{tabular}{|l|c|c|l|}
\hline Lines procured by CPTAs (regional lines) & $\begin{array}{c}\text { Tender } \\
\text { No. }\end{array}$ & Year & Subsidy effect \\
\hline Network in county of Jönköping etc & 1 & 1989 & $-21 \%$ \\
\cline { 2 - 4 } & 2 & 1993 & $-25 \%$ \\
\cline { 2 - 4 } & 3 & 1997 & Minor increase \\
\hline Ystad-Simrishamn & 1 & 1995 & $-18 \%$ \\
\hline \multirow{2}{*}{ Herrljunga-Hallsberg } & 2 & 1998 & $-10 \%$ \\
\cline { 2 - 4 } & 2 & 1994 & $-10 \%$ \\
\cline { 2 - 4 } & 3 & 2002 & Minor increase \\
\hline \multirow{2}{*}{ Borlänge-Malung } & 1 & 1991 & n.a. \\
\cline { 2 - 4 } & 2 & 1994 & $-20 \%$ \\
\cline { 2 - 4 } & 3 & 1996 & Minor \\
\hline Uppsala-Tierp & 1 & 1991 & n.a. \\
\cline { 2 - 4 } & 2 & 1999 & $-20 \%$ \\
\hline Stockholm, commuter trains & 1 & 1998 & $-32 \%$ \\
\cline { 2 - 4 } & 2 & 2005 & $+10 \%$ \\
\hline Lines procured by the state (interregional lines) & Tender & Year & Subsidy effect \\
\hline All lines & No. & & \\
\cline { 2 - 4 } & $1-2$ & $1992-93$ & $-21 \%$ \\
\cline { 2 - 4 } & 7 & $1994-98$ & No increase \\
\cline { 2 - 4 } & 7 & 1999 & $-28 \%$ \\
\hline Northern trains & 10 & 2002 & $-42 \%$ \\
\hline
\end{tabular}

Table 2: Examples of subsidy effects from competitive tenders

Source: Press releases and other documentation from the CPTAs and Rikstrafiken.

The investments have resulted in new lines and tracks upgraded for higher speed and increased safety. However, it is a bit worrying that regional development policies to such an extent have come to influence where public spending on infrastructure is made. Much money is directed to large-scale infrastructure projects (like the new Botnia Link), without any guarantee that the operators will actually be able and willing to run commercial services on these new lines in the future.

The main principle behind the track access charges is that they should amount to the incurred marginal costs of Banverket in terms of track operation and maintenance. In 2004, the total income from track charges amounted to 426 million SEK, corresponding to $11 \%$ of Banverket's total funds directed to operation and maintenance (Banverket, 2005b).

\subsection{Travelling and transportation volumes}

The transportation volumes (in terms of passenger kilometers) have increased by more than $40 \%$ between 1990 and 2003. Looking closer at the development since 1995, it is clear that no other mode has experienced a stronger growth in terms of passenger kilometers. Behind an increase of 32\%, we find that the growth in short-distance regional transportation has been particularly strong (up more than 70\%), while long-distance 
traveling (more than $100 \mathrm{~km}$ ) increased by 15\% (SIKA, 2005). For the freight sector, transportation (measured as ton kilometers) went up by 5\% between 1990 and 2003.

\subsection{Employment and profitability}

All in all, the railway companies and their supporting organizations employed almost 19.000 people in 2003. In comparison, the corresponding businesses had about 34.000 employees in 1987, when they were still parts of SJ. Since the transportation volumes have increased substantially during this period, labor productivity (for those directly involved in traffic operations) increased from five to nine train kilometers per employee between 1990 and 1999 (SOU 2005:4).

Many operators have suffered from low profitability, and numerous small operators have filed for bankruptcy. However, in 2005, a dramatic turn towards profitability became evident for most of the major players: SJ Ltd, Green Cargo and EuroMaint.

\subsection{Ticket prices}

Banverket has investigated the development of ticket prices during the period of 19882003 (Table 3). From this, it is evident that prices have increased substantially more than the Consumer Price Index. Some of this increase may be explained by the introduction of VAT in 1991 but more important is the introduction of a more differentiated price structure as the X2000 high speed trains replaced many cheaper InterCity trains. For the regional services, it seems as if the CPTAs have rather increased ticket prices than the level of subsidization through taxes. Although the prices have increased, it may also be argued that passengers are getting improved services. In view of how traveling by train has developed (as presented above), it appears as if people have actually been willing to pay for this. However, the relative cost of using other modes of transportation may also be an explaining factor.

\begin{tabular}{|l|l|}
\hline & Change 1988-2003 \\
\hline Ticket prices (current prices) & $+125 \%$ \\
\hline Consumer Price Index & $+57 \%$ \\
\hline Ticket prices (adjusted for inflation) & $+43 \%$ \\
\hline Value Added Tax (VAT)* & $+6 \%$ \\
\hline Price excluding VAT (operator revenue) & $+35 \%$ \\
\hline Ticket price adj for inflation: X2000 & $+53 \%$ \\
\hline Ticket price adj for inflation: regional trains & $+59 \%$ \\
\hline Ticket price adj for inflation: InterCity/night trains & $+24 \%$ \\
\hline
\end{tabular}

Table 3: Development of ticket prices 1988-2003

Note: * VAT on traveling changed several times during the period. Before 1991 it was 0\%. In 1991 it was introduced at 25\%, to be lowered to $18 \%$ in 1992 and 12\% in 1993 (after a temporary rise to 21\%). Since 1999 it has been stable at $6 \%$.

Source: Banverket (2005a). 


\section{Conclusions}

The Swedish deregulation of railway services started off as a process of reforms without any clear intentions to introduce competition or increasing the involvement of private actors, neither national nor international. Nevertheless, this was what the path came to lead to. The driving forces of the development have been SJ's recurrent problems, coupled with political objectives to save railway lines from closure, improve sector efficiency, increase railway travel and transfer freight transportation from the roads to the railways. In relative terms, there has been much more focus in Sweden on inter-modal competition than on intra-modal competition, especially when compared to the objectives on the EU level. The major reforms in the late 1980s and early 1990s were also by and large initiated independently of any European railway policies (Sweden joined the European Union in 1995). Actually, only the very recent reforms have occurred as direct consequences of EU directives and regulations. During the last seven years, the Swedish railway sector has moved much closer to privatization and internationalization. The institutional framework regulatory agencies, ownership of firms, norms, and vertical disintegration of the value chain - has in nearly all aspects changed to such an extent that a complete deregulation is now possible. The one resource that perhaps more than any other has been debated during the Swedish deregulation process is the rolling stock and the access to suitable vehicles for other actors than SJ. During the process of deregulation, these problems have at least partially being solved. For the regionally tendered services, the CPTAs provide the operators with the necessary rolling stock, either by themselves or via their rolling stock company Transitio. Rikstrafiken may (via ASJ) provide vehicles to operators of tendered inter-regional services.

The Swedish railway market is not totally open for competition. State-owned SJ Ltd has a share of nearly $75 \%$ of the market for passenger train services, partly protected by the exclusive right to run those inter-regional lines that do not require operational subsidies. The four biggest firms have about 95\% of this market. Two state-owned firms still dominate the open-entry freight market: Green Cargo and MTAB. In reality, MTAB is a monopolist on the iron ore line in northern Sweden and Norway.

Following the stepwise vertical and horizontal disintegration of SJ, barriers to entry are low but passenger train operating companies face uncertainty about their survival due to the repeated tendering. Data from both Great Britain and Sweden show that firms have problems winning tenders for the same traffic two times in a row. Transaction costs have been of some importance in the creation of organizations performing the competitive tenders and regarding some litigation costs after tenders. In practice, the number of present operators and the low barriers to entry suggest that the competitive tenders have been workable competitive despite relatively few bidders taking part in the average tender. However, in a long-term perspective, a persistent low number of bidders may create opportunities for strategic bidding by dominant firms (Alexandersson and Hultén, 2006). It is therefore a promising sign that the number of bidders has increased during the last year. The competitive tenders of passenger services have resulted in reductions in operational subsidies in the magnitude of $20 \%$. Services threatened by closure have thereby often been possible to keep or even develop without additional costs. In the freight sector, the transportation buyers have been able to gain from reduced costs of transportation due to competition. Several of the new and minor freight operators have succeeded in developing new business concepts, thereby shifting freight from the roads to the railways. 
The decentralization of responsibility for the unprofitable regional lines placed responsibility among the actors most committed to continuing and developing these lines. The result has commonly been a revival of the services and better co-ordination with local and regional bus services. In some cases though, it is likely that some rail services have been saved that - from a socio-economic and even an environmental point of view should rather have been replaced by bus services. The restructuring of the Swedish railway sector coincides with several improvements in measurable figures, although the cause-andeffect relationships are not always clear. The transportation volumes have increased substantially, in particular regarding the passenger services. Since the number of employees in the sector has simultaneously decreased, labor productivity has also increased.

It is quite possible that the disintegration of the railway network and the increased competition from new train operators have resulted in some sub-optimization and loss of scale economies. However, it is also clear that the former monopoly did not have strong enough incentives to rationalize and exploit economies of scale. The reorganization of the railways and the tendering system has put the focus on operational cost efficiency.

In several respects, the reforms have improved the Swedish railway system but the deregulation has also been very costly for the taxpayers. It is clear that the many incremental steps have resulted in a situation with several competing models for how the railway services should be handled and organized: a) with SJ as a monopolist on profitable lines specified by SJ, b) with open access for freight operators (to some extent limited by already established services), c) under national tendered contracts where the operator bears the revenue risk (net cost contracts), d) under regional tendered contracts where the CPTAs bear the revenue risk (gross cost contracts), e) under contracts between SJ and CPTAs that have not been tendered, and f) with private monopoly firms on commercially attractive lines such as the Arlanda Airport Link. Consequently, despite more than fifteen years of deregulation and liberalization, and tens of billions of Swedish crowns in subsidies, the Swedish railway sector continues to be in search of a unified stable regulatory structure.

The Swedish deregulation process has advanced in an incremental manner, with periods of relative calm following more or less radical reforms. The regulatory structure has now remained virtually unchanged for more than five years. There seem to be no immediate need for reform: most operators and suppliers are profitable, new firms show willingness to enter the market, the key firms are profitable, the freight and passenger markets are growing, the number of bidders in the competitive tenders are moving slightly upwards and more and more regional networks are put out to tender. Therefore, it is probable that the current state of the deregulated Swedish railway system is more sustainable than at the earlier pauses in railway reform (1989-1991, 1993-1995 and 19972000).

Nevertheless, the regulators will sooner or later have to deal with some inconsistent features of the Swedish regulatory framework. In the long run, it is not feasible to keep SJ Ltd's exclusive right to run commercially passenger services without any obligations linked to this privilege. Currently, SJ may for example change these services at will, basically without any obligation regarding the overall level of supply, the stations used, the ticket prices or the coordination with adjacent services run by other operators. Another problem is the expansion of the subsidized part of the network, and in particular the CPTA-managed lines. In order to meet customer demand and also offset the unreliable long-term supply of SJ Ltd, several CPTAs seek to expand and coordinate their services 
into larger networks. This highlights the need to clarify the interface between commercial and subsidized lines and which of these that should take precedence.

Once among the pioneers of railway reforms, further steps in Sweden are now much more influenced by agreements upon common EU policies. The development on the EU level is not pointing in a single direction. The goal to continue the liberalization of European railways, characterizing the three railway packages, does not seem entirely compatible with the recent work on a new regulation for public service contracts, where the preservation of most national practices and even protectionism appears legitimate. In this state of confusion, it may prove wise for Sweden to go ahead with further reforms, primarily for the development of competencies and companies that are now no longer integrated parts of the national railway operator. Once deregulation in Europe moves on, these firms will benefit from having had the chance to adapt early to more market-like conditions.

\section{$9 \quad$ References}

Alexandersson, G. (2002) Competitive Tendering of Railway Services in Sweden. Origin, Diffusion and Effects from an Institutional Perspective, Paper presented at the ISNIE Conference, Boston, 27-29 September.

Alexandersson, G. and S. Hultén (2006) Competitive Tendering of Regional and Interregional Railway Services in Sweden, paper presented at the ECMT Workshop on Competitive Tendering for Passenger Rail Services, Paris.

Alexandersson, G., S. Hultén, L. Nordenlöw, and G. Ehrling (2000) Spåren efter avregleringen, KFB-report 2000:25, Stockholm: KFB/Banverket [in Swedish].

Banverket, (2004) Annual Report 2003.

Banverket, (2005a) Swedish Rail Sector Development. Banverket’s Sector Report 2004.

Banverket, (2005b) Annual Report 2004.

Borenstein, S., J. Farrell and A. B. Jaffe (1998) “Inside the Pin-Factory: Empirical Studies Augmented by Manager Interviews. Introduction,” Journal of Industrial Economics, 46: 123-124.

European Commission (2005) Proposal for a regulation by the European Parliament and the Council on Public Passenger Transport Services by Rail and by Road, COM(2005) 319 final, 2000/01212 (COD), Brussels.

Finch, J. H. (2002) “The Role of Grounded Theory in Developing Economic Theory," Journal of Economic Methodology, 9: 213-234.

Ehrmann, T. (2003) What can Regulatory Economics Learn from Franchise Systems? Some Additional Arguments for Vertical Integration of Railway Companies, paper 
presented at the First Conference on Railroad Industry Structure, Competition and Investment, Toulouse, 7-8 November.

Héritier, A., D. Kerwer, C. Knill, D. Lehmkuhl, M. Teutsch and A-C. Douillet (2001) Differential Europe: The European Union Impact on National Policymaking. Rowman \& Littlefield: Lanham.

Levin, R. C. (1981) "Railroad Regulation, Deregulation, and Workable Competition," American Economic Review, 71: 394-398.

McFarland, H. (1987) "Did Railroad Deregulation lead to Monopoly Pricing? An Application of $q$," The Journal of Business, 60: 385-400.

Nash, C. A. (1993) “British Bus Deregulation,” The Economic Journal, 103: 1042-1049.

Nash, C. A. \& B. Matthews (2003) Rail Infrastructure Charges - The Issue of Scarcity, paper presented at the First Conference on Railroad Industry Structure, Competition and Investment, Toulouse, 7-8 November.

Nash, C. and A. Smith (2006) Passenger Rail Franchising - British Experience, Paper presented at the ECMT Workshop on Competitive Tendering for Passenger Rail Services, Paris.

Nilsson, J-E. (1995) “Swedish Railways Case Study,” in R. Kopicki \& L. S. Thompson (ed.), Best Methods of Railway Reconstructuring, CFS Discussion Paper Series, No. 111. The World Bank.

Nilsson, J-E. (2002) "Restructuring Sweden's Railways: The Unintentional Deregulation," Swedish Economic Policy Review, 9: 229-254.

Preston, J. (2001) "An Overview of Public Transport Reforms in Great Britain and Forecasts for the Future,” International Journal of Transport Economics, 28: 23-48.

Proposition (2002/03:86), Åtgärder för att stärka den finansiella ställningen i SJ AB [in Swedish], Näringsdepartementet, Stockholm.

Railway Gazette International (2006), “CP Embraces Best Practice,” 162: 88-90.

SIKA, (2005), Kommunikationer, No. 3 [in Swedish]. Statens Institut för Kommunikationsanalys: Östersund

SFS 2004:519, Järnvägslag [in Swedish], Näringsdepartementet: Stockholm.

SFS 2004:526, Järnvägsförordning [in Swedish], Näringsdepartementet: Stockholm

SOU (2005:4), Liberalisering, regler och marknader. Betänkande av Regelutredningen [in Swedish], Fritzes: Stockholm

Uri, N. D. and E. J. Rifkin (1985) "Geographic Markets, Causality and Railroad Deregulation,” The Review of Economics and Statistics, 67: 422-428. 
Van Bergeijk, P. A. G., A. L. Bovenberg, E. E. C. Damme and J. Van Sinderen (1997) Economic Science and Practice: The Roles of Academic Economists and Policy-makers. Edward Elgar: Cheltenham

Van de Velde, D. M. (1999) Changing Trains. Railway Reform and the Role of Competition: The Experience of Six Countries. Aldershot U.K./Brookfield VT: Ashgate.

Vickers, J. and G. Yarrow (1991) “Economic Perspectives on Privatization,” Journal of Economic Perspectives, 5: 111-132.

Westgren, R. and K. Zering (1998) "Case Study Research Methods for Firm and Market Research,” Agribusiness, 14: 415-423.

Wilson, W. W. (1994) “Market-specific Effects of Railroad Deregulation,” The Journal of Industrial Economics, 17: 1-22.

Yvrande-Billon, A. and Ménard, C. (2005) "Institutional Constraints and Organizational Changes: The Case of the British Rail Reform," Journal of Economic Behavior \& Organization, 56: 675-699. 